\title{
Green synthesis, characterization, and anticancer activity of hyaluronan/zinc oxide nanocomposite
}

\author{
This article was published in the following Dove Press journal: \\ OncoTargets and Therapy \\ 26 July 2016 \\ Number of times this article has been viewed
}

\author{
Farideh Namvar ${ }^{1,2}$ \\ Susan Azizi ${ }^{3}$ \\ Heshu Sulaiman Rahman ${ }^{4-6}$ \\ Rosfarizan Mohamad ${ }^{1,3}$ \\ Abdullah Rasedee ${ }^{4}$ \\ Mozhgan Soltani \\ Raha Abdul Rahim ${ }^{7}$ \\ 'Institute of Tropical Forestry \\ and Forest Products (INTROP), \\ Universiti Putra Malaysia, UPM \\ Serdang, Selangor, Malaysia; ${ }^{2}$ Research \\ Center for Animal Development \\ Applied Biology, Mashhad Branch, \\ Islamic Azad University, Mashhad, \\ Iran; ${ }^{3}$ Department of Bioprocess \\ Technology, Faculty of Biotechnology \\ and Biomolecular Sciences, \\ ${ }^{4}$ Department of Veterinary Laboratory \\ Diagnosis, Faculty of Veterinary \\ Medicine, Universiti Putra Malaysia, \\ UPM Serdang, Selangor, Malaysia; \\ ${ }^{5}$ Department of Clinic and Internal \\ Medicine, College of Veterinary \\ Medicine, University of Sulaimani, \\ ${ }^{6}$ Department of Laboratory Medical \\ Sciences, Komar University of Science \\ and Technology, Sulaimani City, \\ Kurdistan Region, Northern Iraq; \\ ${ }^{7}$ Department of Cell and Molecular \\ Biology, Faculty of Biotechnology and \\ Biomolecular Sciences, Universiti \\ Putra Malaysia, UPM Serdang, Selangor, \\ Malaysia
}

Correspondence: Rosfarizan Mohamad; Susan Azizi

Department of Bioprocess Technology, Faculty of Biotechnology and

Biomolecular Sciences, University Putra Malaysia, 43400 UPM Serdang, Selangor, Malaysia

Tel +60 389463455

Fax +6038946 I07I

Email farizanmohd@gmail.com; azisusan@gmail.com

\begin{abstract}
The study describes an in situ green biosynthesis of zinc oxide nanocomposite using the seaweed Sargassum muticum water extract and hyaluronan biopolymer. The morphology and optical properties of the hyaluronan/zinc oxide $(\mathrm{HA} / \mathrm{ZnO})$ nanocomposite were determined by Fourier transform infrared spectroscopy, X-ray diffraction, field emission scanning electron microscopy, transmission electron microscopy, and ultraviolet-vis analysis. Electron microscopy and X-ray diffraction analysis showed that the zinc oxide nanoparticles were polydispersed with a mean size of $10.2 \pm 1.5 \mathrm{~nm}$. The nanoparticles were mostly hexagonal in crystalline form. The HA/ZnO nanocomposite showed the absorption properties in the ultraviolet zone that is ascribed to the band gap of zinc oxide nanocomposite. In the cytotoxicity study, cancer cells, pancreatic adenocarcinoma (PANC-1), ovarian adenocarcinoma (CaOV-3), colonic adenocarcinoma (COLO205), and acute promyelocytic leukemia (HL-60) cells were treated with HA/ $\mathrm{ZnO}$ nanocomposite. At 72 hours of treatment, the half maximal inhibitory concentration $\left(\mathrm{IC}_{50}\right)$ value via the 3-(4,5-dimethylthiazol-2-yl)-2,5-diphenyltetrazolium bromide (MTT) assay was $10.8 \pm 0.3 \mu \mathrm{g} / \mathrm{mL}, 15.4 \pm 1.2 \mu \mathrm{g} / \mathrm{mL}, 12.1 \pm 0.9 \mu \mathrm{g} / \mathrm{mL}$, and $6.25 \pm 0.5 \mu \mathrm{g} / \mathrm{mL}$ for the PANC-1, CaOV-3, COLO-205, and HL-60 cells, respectively, showing that the composite is most toxic to the HL-60 cells. On the other hand, $\mathrm{HA} / \mathrm{ZnO}$ nanocomposite treatment for 72 hours did not cause toxicity to the normal human lung fibroblast (MRC-5) cell line. Using fluorescent dyes and flow cytometry analysis, $\mathrm{HA} / \mathrm{ZnO}$ nanocomposite caused $\mathrm{G} 2 / \mathrm{M}$ cell cycle arrest and stimulated apoptosis-related increase in caspase- 3 and -7 activities of the HL-60 cells. Thus, the study shows that the $\mathrm{HA} / \mathrm{ZnO}$ nanocomposite produced through green synthesis has great potential to be developed into an efficacious therapeutic agent for cancers.
\end{abstract}

Keywords: green synthesis, hyaluronan, zinc oxide nanocomposite, anticancer activity

\section{Introduction}

Hybrid polymer/inorganic nanocomposite materials are a combination of polymer and inorganic phase particles, in which at least one phase is in the nanometer range. Polymer nanocomposite materials display enhanced properties, ie, properties which are significantly more than the properties of the sum of the properties of each individual phase. With its unique optical, electronic, medical, and mechanical properties, the hybrid polymer/inorganic nanocomposites are favorable for many applications. ${ }^{1}$ In recent years, there has been a lot of research in the development of hybrid polymer/ inorganic nanocomposites that have potential applications in biomedical applications. Of particular interest has been the development of hybrid polymer/inorganic nanocomposites comprising of natural biopolymers, such as hyaluronan, with its biological functions and exclusive physicochemical properties, and zinc oxide nanoparticles, which is well known for its biomedical applications and UV shielding ability. ${ }^{2} \mathrm{HA}$ belongs to a class of glycosaminoglycan and is also recognized as a mucopolysaccharide. It is one 
of the major elements of connective tissues, particularly, the dermis and epidermis. Approximately 35\% of human HA is in the muscles and skeleton. ${ }^{3-5}$ Other parts of the body rich in HA include the vitreous humor, synovial fluid, and umbilical cord. HA is a high-molecular weight unsulfated polysaccharide and depending on the source can range from $10^{4} \mathrm{Da}$ to $10^{7} \mathrm{Da}$ in mass. ${ }^{6}$ This polymer is composed of $\mathrm{D}$-glucuronic acid and $N$-acetyl glucosamine residues connected by $\beta-1-3$ and $\beta$-1-4 glycosidic links.

HA due to its high water-holding capacity, mucoadhesion, viscoelasticity, nonimmunogenicity, and biocompatibility is ideal for application as a drug delivery system in ophthalmology, orthopedics, rheumatology, and tissue engineering. ${ }^{7}$ In cosmetics, the low-molecular weight HA is used as a moisturizer and lubricating agent. ${ }^{8}$ High-molecular weight HA can be obtained through the manipulation of bacterial fermentation process. The application of high-molecular weight HA in cosmetics and therapeutics is yet to be determined. ${ }^{9}$

The hybrid polymer/inorganic nanocomposites can be prepared by in situ or ex situ method using either chemical or physical techniques. In the in situ method, the nanoparticles are synthesized while in mixture with the polymers. In the ex situ method, the nanoparticle and polymer matrices are prepared separately, and the nanoparticles are dispersed in the polymers. ${ }^{10}$ In the chemical technique, toxic compounds are generally used, and this restricts the application of the polymer nanocomposite from biological and biomedical applications. To overcome the problem of toxicity, an ecological green approach was introduced to the synthesis of the nanoparticles. ${ }^{11}$

Marine algae have long been used in nutrition and traditional medicine because of their richness in lipids, minerals, vitamins, proteins, polysaccharides, and polyphones. The traditional applications of the algae are the treatment of oxidative stress, allergies, inflammation, cancers, hyperlipidemia, hypertension, and thrombosis. ${ }^{12}$ The phytochemical components of the algae including hydroxyl, carboxyl, and amino groups could benefit in the production of inorganic nanoparticles. ${ }^{13}$

Nanoparticles are fast becoming promising agents for drug delivery in the treatment of diseases. Currently, there are several nanoparticle delivery systems that have been developed for cancer therapy, including liposomes, polymerdrug conjugates, and micellar formulations. ${ }^{14}$ More recently, nanoparticle drug systems are becoming more sophisticated with the incorporation of multifunctional and targeting capabilities that could potentially overcome drug resistance and improve treatment of metastatic diseases. ${ }^{15}$

To the best of our knowledge, this study is a first report on green synthesis of hyaluronan/ZnO nanocomposite
( $\mathrm{HA} / \mathrm{ZnO})$ for the treatment of cancers. The challenges in developing this drug delivery system include the identification of tumor-specific targeting moieties, integration of these moieties into nanocarriers, and formulation of a delivery system with drug-sustained release properties.

\section{Materials and methods Materials}

Zinc acetate dihydrate $\left(\mathrm{Zn}[\mathrm{Ac}]_{2} \cdot 2 \mathrm{H}_{2} \mathrm{O}\right)(99 \%)$ (Merck) and sodium hydroxide $(\mathrm{NaOH})$ (Sigma-Aldrich Co., St Louis, MO, USA) were of analytical grade. The seaweed Sargassum muticum specimens obtained from the seaside regions of Persian Gulf Sea were washed and freeze-dried and milled into powder. The HA polymer was obtained via bacterial fermentation. ${ }^{9}$

\section{Methods}

\section{Preparation of $\mathrm{HA} / \mathrm{ZnO}$ polymer nanocomposite}

The HA solution (100 mL, 1.0\% w/v) was prepared by solubilizing HA in sodium hydroxide $(1.0 \% \mathrm{w} / \mathrm{v})$ with constant stirring for 1 hour. The nanoparticles were synthesized by suspending $1.0 \mathrm{~g}$ of seaweed in $100 \mathrm{~mL}$ of distilled water in a $200 \mathrm{~mL}$ Erlenmeyer flask heating to $100^{\circ} \mathrm{C}$ and filtering through a Whatman 41 filter paper to obtain the seaweed extract. The zinc acetate dehydrate $(1 \mathrm{mM})$ aqueous solution was mixed to $50 \mathrm{~mL}$ of water extract seaweed and added to HA solution under constant stirring for 2-3 hours at $70^{\circ} \mathrm{C}$. A solid nanocomposite product, the $\mathrm{HA} / \mathrm{ZnO}$ nanocomposite, was obtained from the suspension by centrifugation at $200 \times g$ (Hettich zentrifugen, 32 R) for 8 minutes, washed with distilled water, and dried for 4 hours at $100^{\circ} \mathrm{C}$, before storing in air-tight bottles at room temperature until use.

\section{Characterization of $\mathrm{HA} / \mathrm{ZnO}$ nanocomposite}

$\mathrm{X}$-ray diffraction (XPert Pro) analysis was used to determine phase purity and particle size of dried seaweed powder samples using $\mathrm{CuK} \alpha$ radiation $(\lambda=1.542 \AA ; 40 \mathrm{kV}, 30 \mathrm{~mA}$ ) at ambient temperature. The chemical compositions were analyzed using Fourier transform infrared (FTIR) spectroscopy (Perkin-Elmer 1725X). The size and shape of the nanoparticles were determined using a Hitachi H-7100 transmission electron microscope (TEM) operated at an acceleration voltage of $120 \mathrm{kV}$. The size distribution and mean size of the nanoparticles were determined by the Sigma-Scan Pro Software (IBM Corporation, Armonk, NY, USA). The field emission scanning electron microscopy (FESEM) was performed using the Philips model JSM-6360LA machine. UV-visible absorption of solution samples was recorded 
over the range of 200-800 $\mathrm{nm}$ using a UV-vis spectrophotometer, a Lambda 25-Perkin Elmer. The polydispersity index was obtained by dynamic light scattering using the dispersion technology and light scattering system HPPS software v 4.20 .

\section{Cell culture condition}

The pancreatic adenocarcinoma (PANC-1), ovarian adenocarcinoma (CaOV-3), colonic adenocarcinoma (COLO205), acute promyelocytic leukemia (HL-60), and normal human lung fibroblast (MRC-5) cell lines were purchased from American Type Culture Collection (ATCC) (Manassas, VA, USA). The cells were maintained in RPMI-1640 (ATCC) medium, supplemented with L-glutamine (2 mM), 10\% heat-inactivated fetal calf serum (ATCC), 100 units $/ \mathrm{mL}$ penicillin, and $100 \mu \mathrm{g} / \mathrm{mL}$ streptomycin (Sigma-Aldrich Co.), according to the ATCC protocol, cultured, and grown in $75 \mathrm{~cm}^{2}$ culture flasks (TPP, Switzerland) in an incubator with humidified atmosphere of $95 \%$ air and $5 \% \mathrm{CO}_{2}$ at $37^{\circ} \mathrm{C}$ (Binder, Germany). The cell cultures were frequently examined under inverted microscope (Micros, Austria) to determine confluency and viability. The ethics committee of Universiti Putra Malaysia does not deem ethics approval necessary for commercially purchased human cell lines.

\section{Cell growth inhibition assay}

The antiproliferative effect of $1-100 \mu \mathrm{g} / \mathrm{mL} \mathrm{HA} / \mathrm{ZnO}$ nanocomposite on cancer and normal cells was determined by the 3-(4,5-dimethylthiazol-2-yl)-2,5-diphenyltetrazolium bromide (MTT) kit (Sigma-Aldrich Co.). Briefly, the cancer cells were allowed to grow in $75 \mathrm{~cm}^{2}$ cell culture flask (TPP) until $90 \%$ confluent, and the cell density was determined using a hemocytometer (Marienfeld, Germany). Then, $100 \mu \mathrm{L}$ of cell suspension was seeded into each well of the 96-well microculture plates (TPP) each at a concentration of $1 \times 10^{5}$ cells $/ \mathrm{mL}$ and treated with $100 \mu \mathrm{L}$ of various concentrations of HA/ $\mathrm{ZnO}$ nanocomposite. After incubation for 72 hours in a 5\% $\mathrm{CO}_{2}$ incubator at $37^{\circ} \mathrm{C}, 20 \mu \mathrm{L}$ of $5 \mathrm{mg} / \mathrm{mL}$ MTT solution (microculture tetrazolium) (Sigma-Aldrich Co.) in phosphate buffer solution (PBS, pH 7.5) (Sigma-Aldrich Co.) was added to each well, and the plate was covered with aluminum foil and incubated for an additional 4 hours in the dark to allow the metabolically active viable cells to convert water-soluble yellow MTT solution into the water-insoluble purple formazan crystals. Immediately, $100 \mu \mathrm{L}$ of incubating medium was aspirated. The purple formazan was then dissolved with $100 \mu \mathrm{L}$ MTT solubilization solution (Sigma-Aldrich Co.) with mixing and shaking (Eppendorf plate shaker, USA) for 5 minutes. ${ }^{16}$ The assay was performed in triplicates. The optical density was recorded using an ELISA plate reader (Universal Microplate reader) (Biotech Inc., USA) at $570 \mathrm{~nm}$. The half maximal inhibitory concentration $\left(\mathrm{IC}_{50}\right)$ value was determined from the absorbance versus concentration curve. All values from the cells treated with $\mathrm{HA} / \mathrm{ZnO}$ nanocomposite were compared with those treated with the antineoplastic agent, cisplatin (Sigma-Aldrich Co.). Dimethyl sulfoxide (0.1\%)treated cells served as the negative control.

\section{Acridine orange/propidium iodide assay}

The HL-60 cell shown to be most susceptible to $\mathrm{HA} / \mathrm{ZnO}$ nanocomposite was chosen for subsequent analysis. The effect of $\mathrm{HA} / \mathrm{ZnO}$ nanocomposite on the HL-60 cells was determined using the acridine orange/propidium iodide (AO/PI) double staining method according to standard procedure. The cells were examined under a fluorescence microscope (Leica Microsystems, Wetzlar, Germany) with the Q-floro software installed. The HL-60 cells at a concentration of $1 \times 10^{6}$ cells $/ \mathrm{mL}$ were placed in a $25 \mathrm{~cm}^{2}$ culture flask (TPP) and then treated with $\mathrm{IC}_{50}$ concentration of $\mathrm{HA} / \mathrm{ZnO}$ nanocomposites and incubated in a $5 \% \mathrm{CO}_{2}$ incubator for 24 hours, 48 hours, and 72 hours at $37^{\circ} \mathrm{C}$. After treatment, the cells were centrifuged at $200 \times g$ (Hettich zentrifugen, $32 \mathrm{R}$ ) for 10 minutes, and the supernatant discarded. The cells were then washed twice with PBS and centrifuged each time at $200 \times g$ for 10 minutes to remove the medium. Approximately $10 \mu \mathrm{L}$ of the cell pellets were stained for 2 minutes with $10 \mu \mathrm{L}$ fluorescent dyes mixture containing equal volumes $(100 \mu \mathrm{g} / \mathrm{mL})$ of $\mathrm{AO}$ and PI. Approximately $10 \mu \mathrm{L}$ of freshly stained cell suspension was placed onto a glass slide, covered with cover slip, and examined under a fluorescence microscope within 30 minutes before the fluorescence began to fade. ${ }^{17}$

\section{Annexin $\mathrm{V}$-fluorescein isothiocyanate}

The HL- 60 cells at $1 \times 10^{6}$ cells $/ \mathrm{mL}$ per well were treated with $\mathrm{IC}_{50}$ concentration of $\mathrm{HA} / \mathrm{ZnO}$ nanocomposite for 6 hours, 12 hours, and 24 hours. Untreated cells served as controls. The HL-60 cells suspension was then aspirated and centrifuged at $200 \times g$ (Hettich zentrifugen, $32 \mathrm{R}$ ) for 10 minutes to remove the medium. The cell pellets were washed twice with $1 \mathrm{~mL}$ ice-cold PBS, recentrifuged, and resuspended in ice-cold $1 \times$ binding buffer. Precisely $500 \mu \mathrm{L}$ of cell suspension was transferred to a $5 \mathrm{~mL}$ culture tube (TPP), to which $5 \mu \mathrm{L}$ of annexin $\mathrm{V}$-fluorescein isothiocyanate conjugate and $10 \mu \mathrm{L}$ of PI were added. The cells were incubated for $15 \mathrm{~min}-$ utes at room temperature in the dark and then subjected to flow cytometric analysis using the BD FACS Calibur flow cytometer (BD, Franklin Lakes, NJ, USA). The data analysis was performed using the CellQuest Pro software. 


\section{Cell cycle assay}

Flow cytometer analysis was also used to determine the HL-60 cell cytotoxicity of $\mathrm{HA} / \mathrm{ZnO}$ nanocomposite. Briefly, $2.5 \times 10^{6}$ cells $/ \mathrm{mL}$ of HL- 60 cells were cultured with the $\mathrm{IC}_{50}$ concentration of $\mathrm{HA} / \mathrm{ZnO}$ nanocomposite in each well and incubated for 12 hours, 24 hours, and 48 hours. The cells were harvested by centrifugation at $200 \times g$ (Hettich zentrifugen, $32 \mathrm{R}$ ) for 5 minutes and washed with $1 \mathrm{~mL}$ PBS (pH 7.4) containing $0.1 \%$ sodium azide. Then $500 \mu \mathrm{L}$ of $70 \%$ ice-cold ethanol was added to the cell pellets drop by drop with constant mixing to prevent clumping and aggregation and kept at $-20^{\circ} \mathrm{C}$ for 1 week. One milliliter of PBS was added, and the suspension was centrifuged at $200 \times g$ (Hettich zentrifugen, $32 \mathrm{R}$ ) for 5 minutes to pellet cells and remove the ethanol. The cell pellets were washed twice with $1 \mathrm{~mL}$ PBS and stained with PBS staining buffer that contained $0.1 \%$ triton $\mathrm{X}-100,10 \mathrm{mM}$ ethylenediaminetetraacetic acid, $50 \mu \mathrm{g} / \mathrm{mL}$ RNAase A, and $3 \mu \mathrm{g} / \mathrm{mL}$ PI and incubated on ice in dark for 30 minutes..$^{18}$ Flow cytometric analysis was conducted using the BD FACS Calibur flow cytometer (BD), and data analysis was performed using the CellQuest Pro software.

\section{Caspase assay}

To determine if apoptosis is a mode of HL-60 cell death caused by $\mathrm{HA} / \mathrm{ZnO}$ nanocomposite, the caspase- 3 and -9 activities were estimated colorimetrically using the Gene script kit (Piscataway, NJ, USA). Briefly, $1 \times 10^{6} \mathrm{HL}-60$ cells in each well were first treated with $\mathrm{HA} / \mathrm{ZnO}$ nanocomposite for 24 hours, 48 hours, and 72 hours. The medium was aspirated, and the cells were washed with pre-chilled PBS. Cell lysates were prepared by adding $100 \mu \mathrm{L}$ lysis buffer to each well and allowing to stand for 20 minutes on ice to complete cell lysis. After centrifugation at $200 \times g$ (Hettich zentrifugen, $32 \mathrm{R}$ ), the supernatants were collected and the protein concentration was quantified by the Bradford assay. The lysates were finally incubated in the dark at $37^{\circ} \mathrm{C}$ for 4 hours, and the absorption read at $490 \mathrm{~nm}$ in an ELISA microplate reader (Biotech Inc., USA). ${ }^{19}$

\section{Statistical analysis}

The results were expressed as mean \pm standard deviation. The statistical analysis was done using SPSS version 20.0 (IBM Corporation). $P$-values $<0.05$ were assumed to be significant.

\section{Results and discussion Characterization of $\mathrm{HA} / \mathrm{ZnO}$ nanocomposite}

Figure 1 illustrates FTIR spectra of (a) HA, (b) S. muticum, and (c) HA/ZnO nanocomposite. Spectrum (a) confirmed

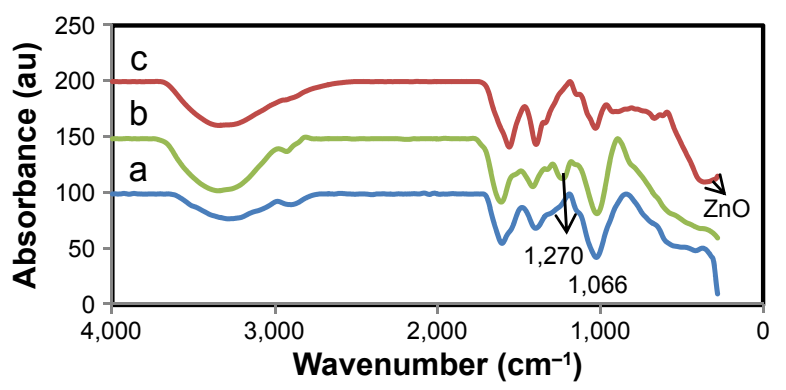

Figure I FTIR spectra of (a) hyaluronan, (b) Sargassum muticum, and (c) $\mathrm{HA} / \mathrm{ZnO}$ nanocomposite.

Abbreviations: FTIR, Fourier transform infrared; $\mathrm{HA}$, hyaluronan; $\mathrm{ZnO}$, zinc oxide.

the presence of $\mathrm{HA}$ with bands at $3,412 \mathrm{~cm}^{-1}, 1,616 \mathrm{~cm}^{-1}$, $1,411 \mathrm{~cm}^{-1}, 1,149 \mathrm{~cm}^{-1}, 1,066 \mathrm{~cm}^{-1}, 946 \mathrm{~cm}^{-1}$, and $661 \mathrm{~cm}^{-1} \cdot 20$ Spectrum (b) represents $S$. muticum with bands at $3,340 \mathrm{~cm}^{-1}$, $1,610 \mathrm{~cm}^{-1}, 1,420 \mathrm{~cm}^{-1}, 1,270 \mathrm{~cm}^{-1}$, and $1,037 \mathrm{~cm}^{-1}$. 21,22 Spectrum (c) represents $\mathrm{HA} / \mathrm{ZnO}$ nanocomposite. The formation of $\mathrm{ZnO}$ nanoparticles is confirmed by a band at $441 \mathrm{~cm}^{-1}$. The band at $1,270 \mathrm{~cm}^{-1}$ is attributed to the asymmetric sulfate stretching vibration, and the peak at $1,066 \mathrm{~cm}^{-1}$ ascribed to symmetric $\mathrm{C}-\mathrm{O}$ vibration related to a $\mathrm{C}-\mathrm{O}-\mathrm{SO}_{3}{ }^{23}$ or the $\mathrm{C}-\mathrm{OH}$ had become weak in the formation of $\mathrm{ZnO}$ nanoparticles, indicating participation of the sulfate groups on polysaccharides of the S. muticum and the hydroxyl groups of both the S. muticum and the HA. On the other hand, the peaks at $\sim 1,632 \mathrm{~cm}^{-1}$ and $1,433 \mathrm{~cm}^{-1}$ correspond to stretching vibration of $(\mathrm{NH}) \mathrm{C}=\mathrm{O}$ and $-\mathrm{COO}$ or $\mathrm{OH}$ groups, respectively. These peaks became strong and shifted slightly with the synthesis of $\mathrm{ZnO}$ nanoparticles, indicating that interactions between the $(\mathrm{NH}) \mathrm{C}=\mathrm{O}$, $-\mathrm{COOH}$, and $\mathrm{OH}$ groups of HA and S. muticum and the - $\mathrm{OH}$ groups of $\mathrm{ZnO}$ nanoparticle surfaces had occurred. These interactions had allowed for the stabilization and capping of $\mathrm{ZnO}$ nanoparticles with HA and S. muticum.

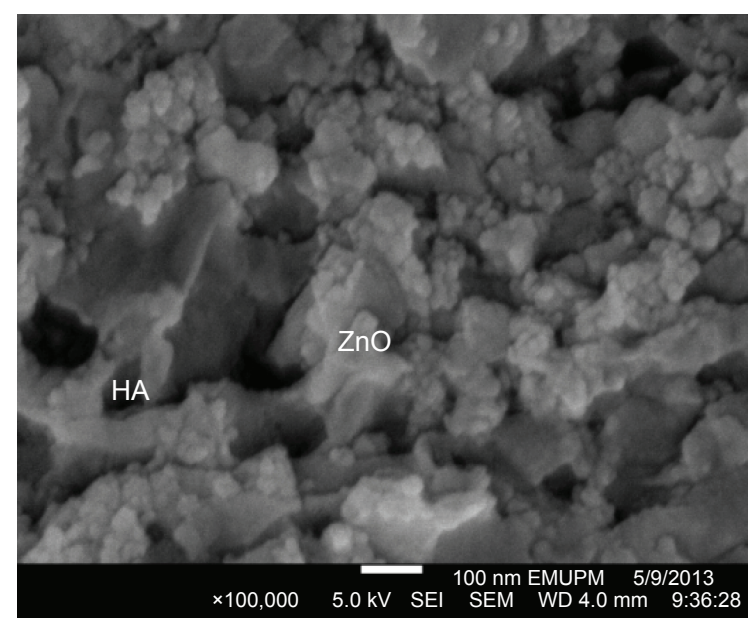

Figure 2 FESEM image of the $\mathrm{HA} / \mathrm{ZnO}$ nanocomposite.

Abbreviations: FESEM, field emission scanning electron microscopy; $\mathrm{HA} / \mathrm{ZnO}$, hyaluronan/zinc oxide. 

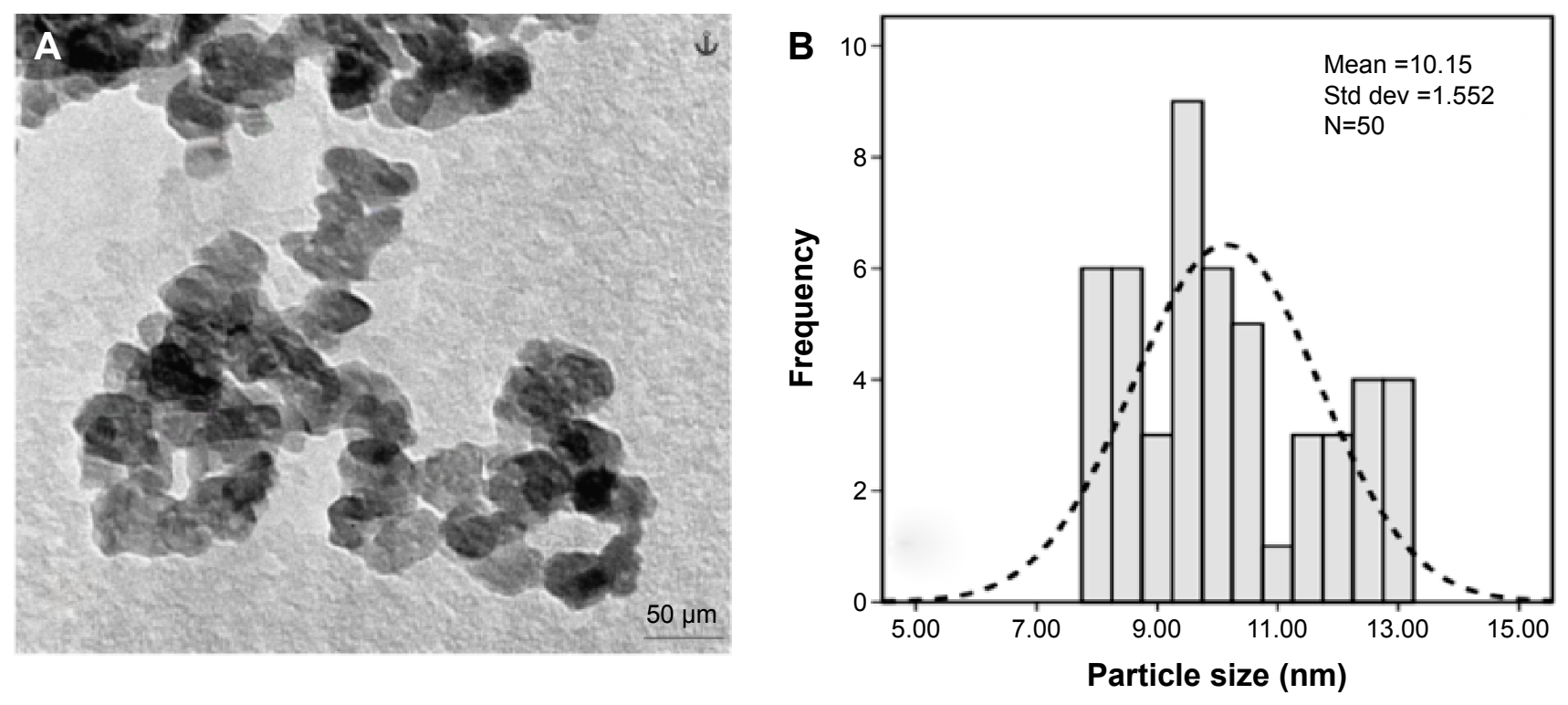

Figure 3 Morphological characteristic of $\mathrm{HA} / \mathrm{ZnO}$ nanocomposite.

Notes: (A) TEM image and (B) particle size distribution of the $\mathrm{HA} / \mathrm{ZnO}$ nanocomposite.

Abbreviations: TEM, transmission electron microscope; HA/ZnO, hyaluronan/zinc oxide; Std dev, standard deviation.

Figure 2 illustrates FESEM image of $\mathrm{HA} / \mathrm{ZnO}$ nanocomposite. The polygonal shapes of $\mathrm{ZnO}$ nanoparticles with a mean diameter of 3-8 $\mathrm{nm}$ are evident on the surface of HA. The results are consistent with the firm binding of $\mathrm{ZnO}$ nanoparticles to HA, and the formation of this complex inhibits nanoparticle aggregation and agglomeration.

The average particle size and distribution of $\mathrm{ZnO}$ nanoparticles were estimated under TEM. The polydispersed $\mathrm{ZnO}$ nanoparticles with the hexagonal wurtzite structure are shown in Figure 3A. The size of the nanoparticles is $10.2 \pm 1.5 \mathrm{~nm}$ (Figure 3B). The TEM image clearly suggests the presence of secondary materials, shown by the dark shadows on the surface of $\mathrm{ZnO}$ nanoparticles, which may be the bioorganic molecules of S. muticum. The interaction between $\mathrm{ZnO}$ nanoparticles and S. muticum was confirmed by FTIR (Figure 1).

Figure 4 illustrates the $\mathrm{X}$-ray diffraction pattern of $\mathrm{HA} / \mathrm{ZnO}$ nanocomposite. The prominent peaks are

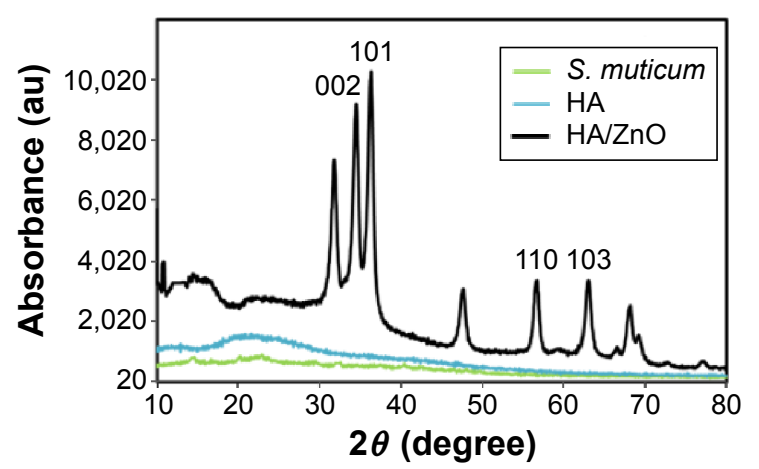

Figure $4 \mathrm{X}$-ray diffraction pattern of the $\mathrm{HA} / \mathrm{ZnO}$ nanocomposite. Abbreviations: $\mathrm{HA}$, hyaluronan; $\mathrm{ZnO}$, zinc oxide; $\mathrm{S}$. muticum, Sargassum muticum. attributed to the hexagonal wurtzite structure of $\mathrm{ZnO}$ (PDF Card: 00-036-1451). Broadening of line and sharpness of the diffraction peaks are evident, indicating that $\mathrm{HA} / \mathrm{ZnO}$ nanocomposite was not only in nanometer range in size but also crystalline. Using the Debye-Scherrer equation, the diameter of the $\mathrm{HA} / \mathrm{ZnO}$ nanoparticles was $\sim 12 \mathrm{~nm}$, which is in agreement with TEM and FESEM results.

A sharp absorption peak can be seen at wavelength $344 \mathrm{~nm}$ (Figure 5), confirming the direct band gap absorption of $\mathrm{ZnO}$ crystals due to the electron transitions from the valence band to the conduction band $\left(\mathrm{O}_{2 \mathrm{p}} \rightarrow \mathrm{Zn}_{3 \mathrm{~d}}\right) \cdot{ }^{24}$ Thus, the results show that incorporation of $\mathrm{ZnO}$ into HA produces nanocomposite with excellent UV light absorbance capacity. The $\mathrm{HA} / \mathrm{ZnO}$ nanocomposite was stable in solution even after 6 months. The polydispersity of $\mathrm{HA}$ and $\mathrm{HA} / \mathrm{ZnO}$ nanocomposite is shown in Figure 6. The synthesis of HA/ZnO nanoparticles had decreased the size distribution of HA.

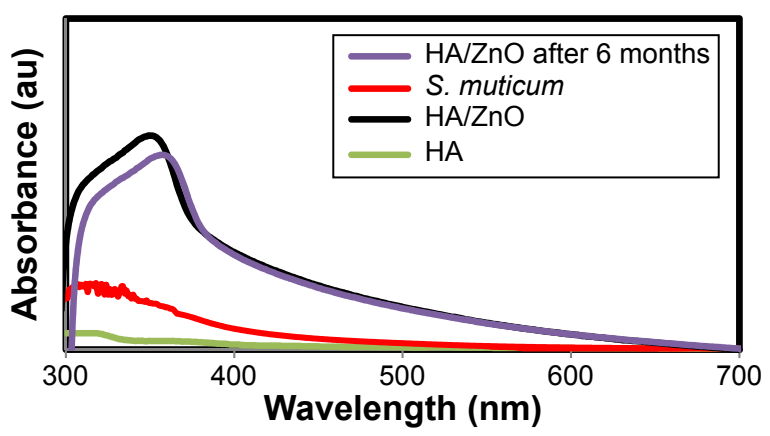

Figure $\mathbf{5}$ UV-vis absorption spectrum of the $\mathrm{HA} / \mathrm{ZnO}$ nanocomposite. Abbreviations: UV, ultraviolet; $\mathrm{HA}$, hyaluronan; $\mathrm{ZnO}$, zinc oxide; S. muticum, Sargassum muticum. 


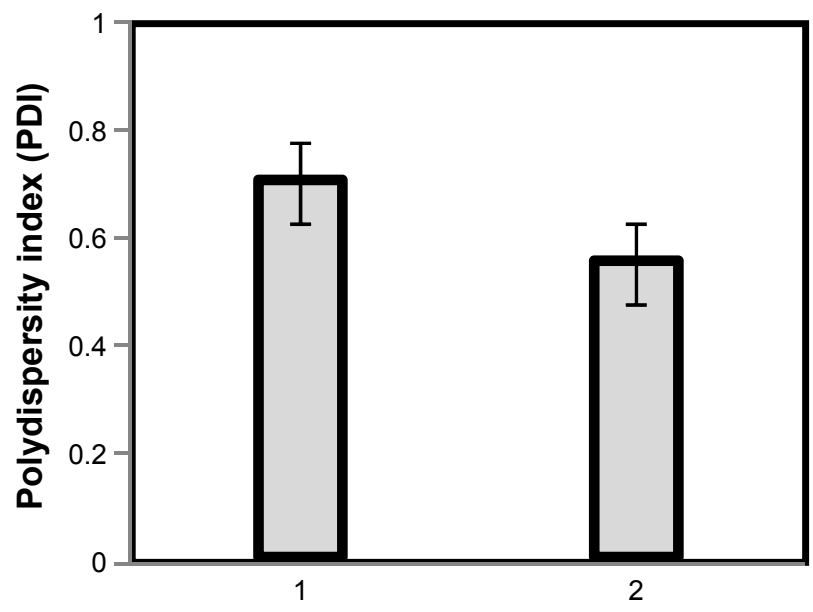

Figure 6 The polydispersity index of the $\mathrm{HA}(\mathrm{I})$ and $\mathrm{HA} / \mathrm{ZnO}(2)$ nanocomposite. Abbreviations: $\mathrm{HA}$, hyaluronan; $\mathrm{ZnO}$, zinc oxide.

\section{$\mathrm{HA} / \mathrm{ZnO}$ nanocomposite inhibits proliferation of human cancer cells}

The cytotoxicity study showed that $\mathrm{HA} / \mathrm{ZnO}$ nanocomposite causes morphological changes and inhibits proliferation of cancer cells in dose- and time-dependent manner (Figure 7A). The $\mathrm{HA} / \mathrm{ZnO}$ was not toxic to normal human lung (MRC-5) cells (Figure 7B). The $\mathrm{IC}_{50}$ values of HA/ $\mathrm{ZnO}$ nanocomposite on cancer cells were $10.8 \pm 0.3 \mu \mathrm{g} / \mathrm{mL}$ for PANC-1, 15.4 $\pm 1.2 \mu \mathrm{g} / \mathrm{mL}$ for CaOV-3, $12.1 \pm 0.9 \mu \mathrm{g} / \mathrm{mL}$ for COLO-205, and $6.25 \pm 0.5 \mu \mathrm{g} / \mathrm{mL}$ for HL-60 cell lines at 72 hours of treatment. In comparison, the $\mathrm{IC}_{50}$ of cisplatin on HL-60 cells was $10 \pm 0.5 \mu \mathrm{g} / \mathrm{mL}, 1.55 \pm 0.73 \mu \mathrm{g} / \mathrm{mL}$, and $1.3 \pm 0.07 \mu \mathrm{g} / \mathrm{mL}$ after 24 hours, 48 hours, and 72 hours treatment, respectively (Figure 7C). The HL-60 cell lines
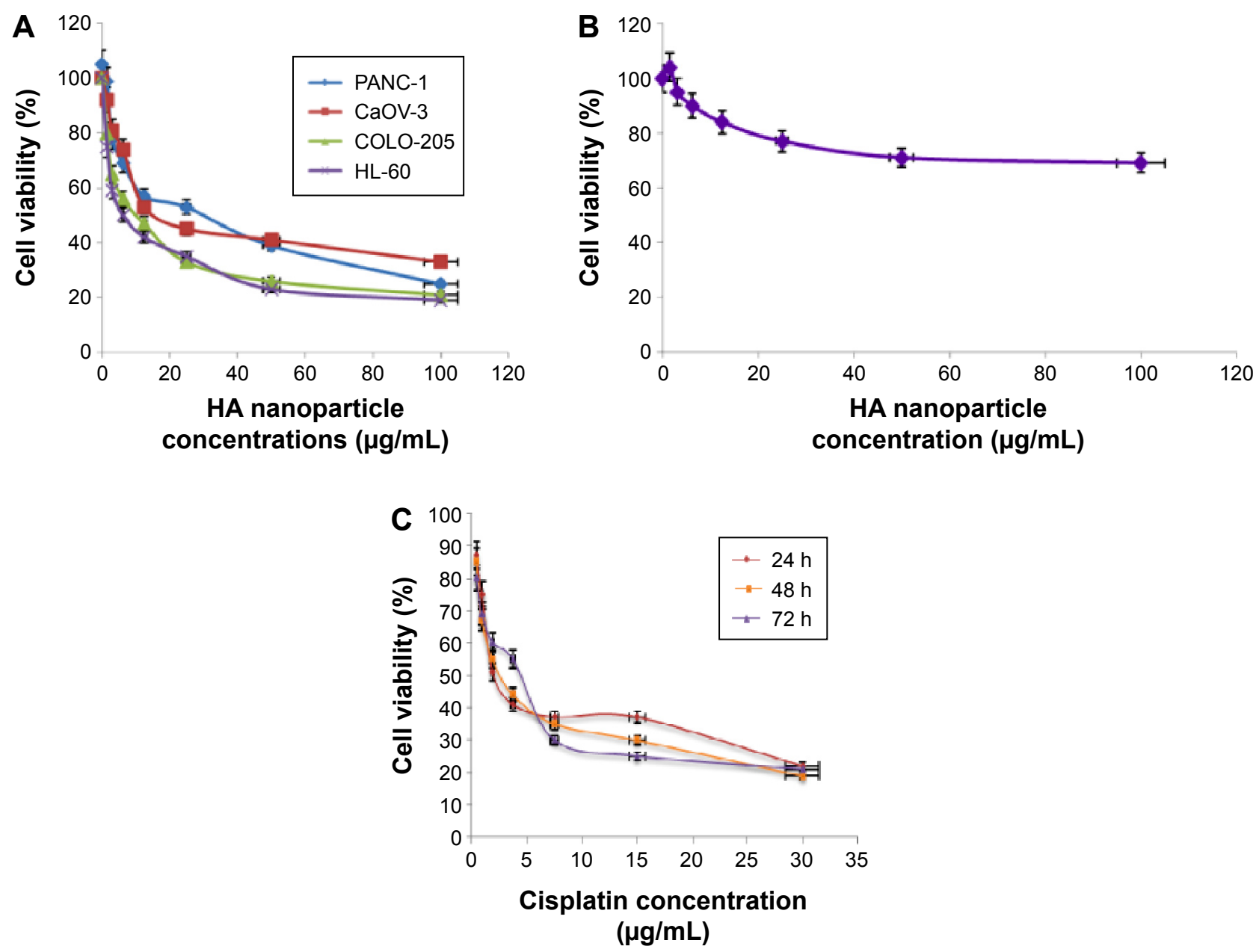

Figure 7 Cytotoxic effect of $\mathrm{HA} / \mathrm{ZnO}$ nanocomposite and Cisplatin using 3-(4,5-dimethylthiazol-2-yl)-2,5-diphenyltetrazolium bromide on various human cell lines. Notes: (A) Cytotoxic effects of $\mathrm{HA} / \mathrm{ZnO}$ nanocomposite on various human cancer cells at $72 \mathrm{~h}$ of treatment were evaluated using MTT assay. Each point is the mean value of three replicates. PANC-I: pancreatic adenocarcinoma cell line, CaOV-3: ovarian adenocarcinoma cell line, COLO-205: colonic adenocarcinoma cell line, HL-60: acute promyelocytic leukemia cells. (B) Cytotoxic effects of $\mathrm{HA} / \mathrm{ZnO}$ nanocomposite on normal human lung fibroblast cell line (MRC-5) at $72 \mathrm{~h}$ of treatment were evaluated using MTT assay. Each point is the mean value of three replicates. (C) Cytotoxic effects of cisplatin on HL-60 cells at $24 \mathrm{~h}, 48 \mathrm{~h}$, and $72 \mathrm{~h}$ of treatment were evaluated through mitochondrial activity using the MTT assay. Each point is the mean value of three replicates.

Abbreviations: $\mathrm{HA} / \mathrm{ZnO}$, hyaluronan/zinc oxide; h, hours; MTT, 3-(4,5-dimethylthiazol-2-yl)-2,5-diphenyltetrazolium bromide. 
were most susceptible to the cytotoxic effect of $\mathrm{HA} / \mathrm{ZnO}$ nanocomposite.

\section{Quantification of apoptosis using AO/PI double staining}

Apoptosis induction is the most sought after effect in cancer therapies. Apoptotic HL-60 cells show several cellular and molecular biological features, such as cell shrinkage, DNA fragmentations, and activation of the caspase cascade with $\mathrm{HA} / \mathrm{ZnO}$ nanocomposite treatment. The $\mathrm{HA} / \mathrm{ZnO}$ nanocomposite also inhibited HL-60 growth in time- and dose-dependent manner (Figure 8). Untreated cells show diffuse green fluorescence, while apoptotic cells showed clumps of intense green fluorescent spots suggesting condensed chromatin during apoptosis of the HL-60 cells. There is also characteristic chromatin condensation in periphery of the nucleus shown by crescent shape and numerous round clumps.

\section{Annexin $\mathrm{V}$-fluorescein isothiocyanate assay}

Annexin is a family of calcium-dependent phospholipidbinding proteins that binds to externalized phosphatidylserine of cells undergoing apoptosis. This was also evident by flow cytometric analysis of $\mathrm{AO} / \mathrm{PI}$-stained $\mathrm{HA} / \mathrm{ZnO}$ nanocomposite-treated HL-60 cells. The distribution of HA/ZnO nanocomposite-treated cells in early apoptosis and late apoptosis was significantly higher than that for the untreated cells (Figure 9; Table 1). In addition, the $\mathrm{HA} / \mathrm{ZnO}$ nanocomposite treatment unlike the nontreatment only slightly decreases the population of viable cells.

\section{Cell cycle assay}

In cells treated with apoptosis-inducing agents, a subpopulation of cells in sub-G1 phase of the cycle should increase. This is the result of endonuclease activation and subsequent
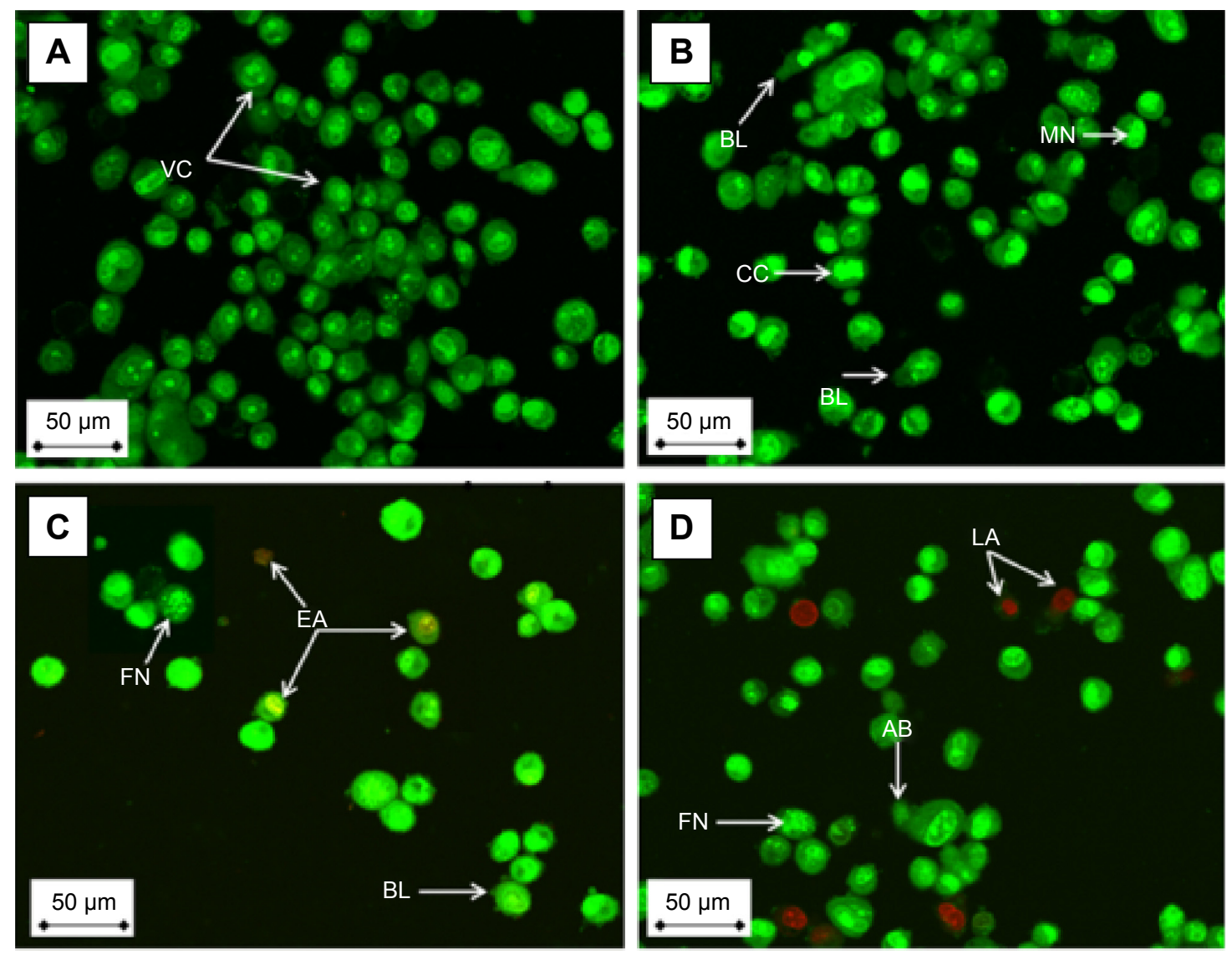

Figure 8 Fluorescent micrograph of AO/PI double-stained HL-60 cells that were treated with $\mathrm{HA} / \mathrm{ZnO}$ nanocomposite.

Notes: (A) Untreated cells showing normal cell structure. (B) Treated cells after $24 \mathrm{~h}$ showing membrane blebbing, nuclear margination, and chromatin condensation. (C) Early apoptotic cells showing blebbing and nuclear fragmentation after $48 \mathrm{~h}$ treatment. (D) Late apoptotic cells showing nuclear fragmentation and apoptotic body formation after $72 \mathrm{~h}$ treatment (magnification 400x).

Abbreviations: $\mathrm{AO} / \mathrm{PI}$, acridine orange/propidium iodide; $\mathrm{HL}-60$, acute promyelocytic leukemia cells; $\mathrm{HA} / \mathrm{ZnO}$, hyaluronan/zinc oxide; VC, viable cells; $\mathrm{BL}$, membrane blebbing; CC, chromatin condensation; MN, marginated nucleus; EA, early apoptotic cells; FN, fragmented nucleus; LA, late apoptotic cells; AB, apoptotic body. 

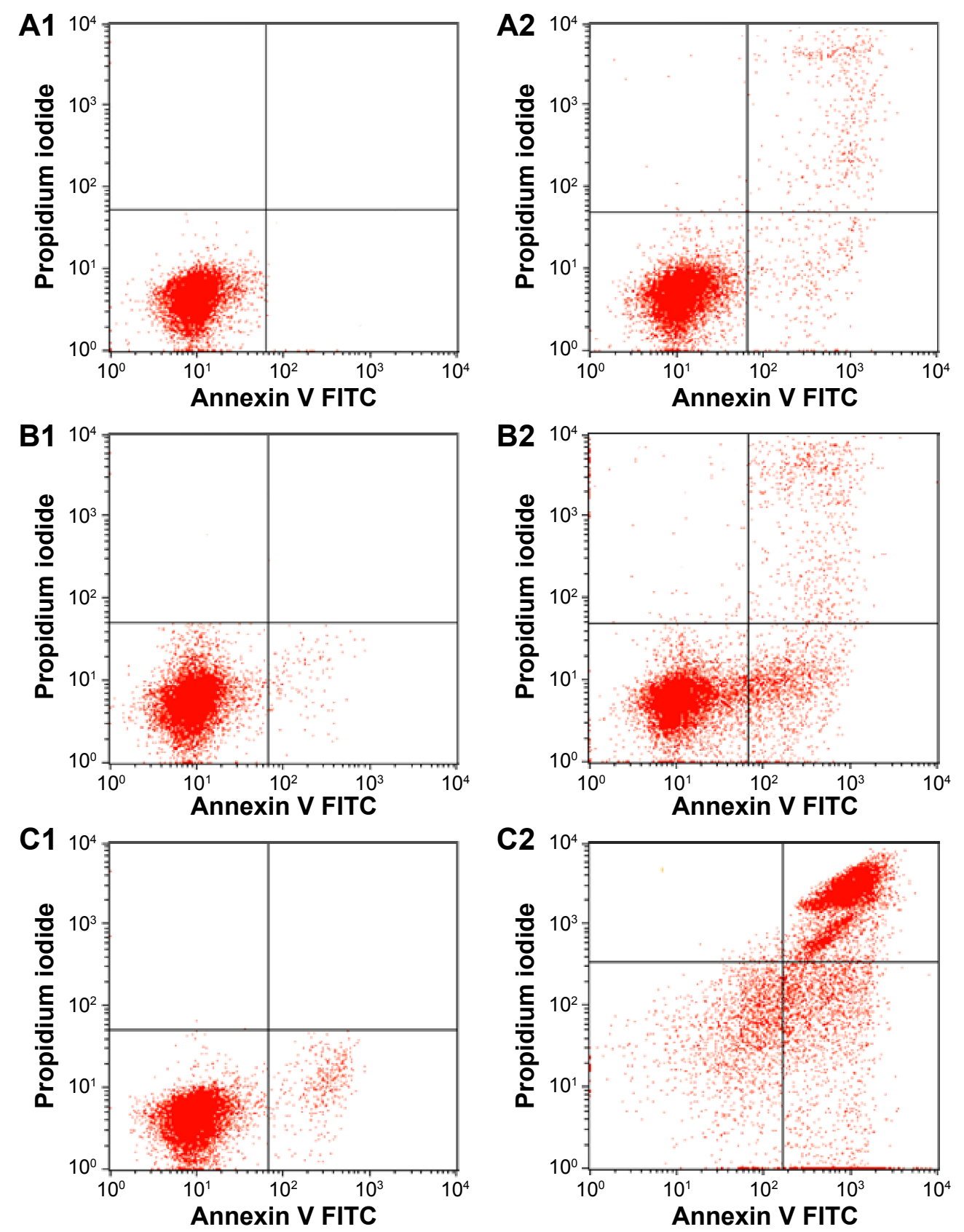

Figure 9 Flow cytometric analysis of apoptosis induction by $\mathrm{HA} / \mathrm{ZnO}$ nanocomposite in $\mathrm{HL}-60$ cells after staining with FITC-conjugated annexin- $\mathrm{V}$ and Pl.

Notes: (AI-CI) Untreated (control) HL-60 cells at 6 h, 12 h, and 24 h incubation, respectively. (A2-C2) Effects of 6 h, 12 h, and 24 h HA/ZnO nanocomposite treatment, respectively.

Abbreviations: $\mathrm{HA} / \mathrm{ZnO}$, hyaluronan/zinc oxide; $\mathrm{HL}-60$, acute promyelocytic leukemia cells; FITC, fluorescein isothiocyanate; PI, propidium iodide; h, hours.

Table I Flow cytometric analysis of HL-60 cells treated with $\mathrm{HA} / \mathrm{ZnO}$ nanocomposite

\begin{tabular}{lllllll}
\hline Cell condition & \multicolumn{1}{l}{ Cells (\%) } & & & & \\
\cline { 2 - 7 } & Control 6 h & Treated 6 h & Control I 2 h & Treated I 2 h & Control 24 h & Treated 24 h \\
\hline Viable cells & $97.4 \pm 0.74$ & $80.29 \pm 0.65$ & $92.30 \pm 0.55$ & $75.29 \pm 0.15$ & $90.7 \pm 0.25$ & $73.5 \pm 0.13$ \\
Early apoptosis & $1.87 \pm 0.15$ & $10.5 \pm 0.99 *$ & $4.95 \pm 0.70$ & $15.00 \pm 0.30^{*}$ & $6.1 \pm 0.45$ & $9.5 \pm 0.22^{*}$ \\
Late apoptosis/necrosis & $0.69 \pm 0.35$ & $8.65 \pm 0.95^{* *}$ & $2.62 \pm 0.50$ & $10.7 \pm 0.80^{* *}$ & $3.8 \pm 0.25$ & $16.9 \pm 0.10^{* *}$ \\
\hline
\end{tabular}

Notes: The cells were stained with FITC-conjugated annexin- $\mathrm{V}$ and $\mathrm{Pl}$ and incubated at $37^{\circ} \mathrm{C}$ for $6 \mathrm{~h}, 12 \mathrm{~h}$, and $24 \mathrm{~h}$. Values are expressed as mean \pm SD of three different experiments. Data have been analyzed using post hoc comparison test, one-way ANOVA, and means compared by Tukey's $b$-test. *Significant $(P<0.05)$ increase of early apoptotic cells in HA/ZNO nanocomposite-treated groups compared to that of untreated control. **Significant $(P<0.05)$ increase of late apoptotic/necrotic cells in $\mathrm{HA} / \mathrm{ZnO}$ nanocomposite-treated groups compared to that of untreated control.

Abbreviations: $\mathrm{HL}-60$, acute promyelocytic leukemia cells; $\mathrm{HA} / \mathrm{ZnO}$, hyaluronan/zinc oxide; h, hours; FITC, fluorescein isothiocyanate; PI, propidium iodide; ANOVA, analysis of variance; SD, standard deviation. 
leakage of DNA from the cells. Since necrotic cells do not show the immediate reduction in DNA content, the distinction between apoptotic and necrotic cells can be made. As shown in Figure 10 and Table 2, there is G2/M cell cycle arrest in the $\mathrm{HA} / \mathrm{ZnO}$ nanocomposite-treated HL-60 cells in a time-dependent manner. The cell population in $\mathrm{G} 2 / \mathrm{M}$ phase increased from $16.85 \% \pm 0.76 \%$ to $20.0 \% \pm 0.41 \%$ after 24 hours, from $19.16 \% \pm 0.26 \%$ to $26.29 \% \pm 0.35 \%$ after 48 hours, and from $22.30 \% \pm 0.22 \%$ to $27.06 \% \pm 0.93 \%$ after 72 hours of exposure to $\mathrm{HA} / \mathrm{ZnO}$ nanocomposite.
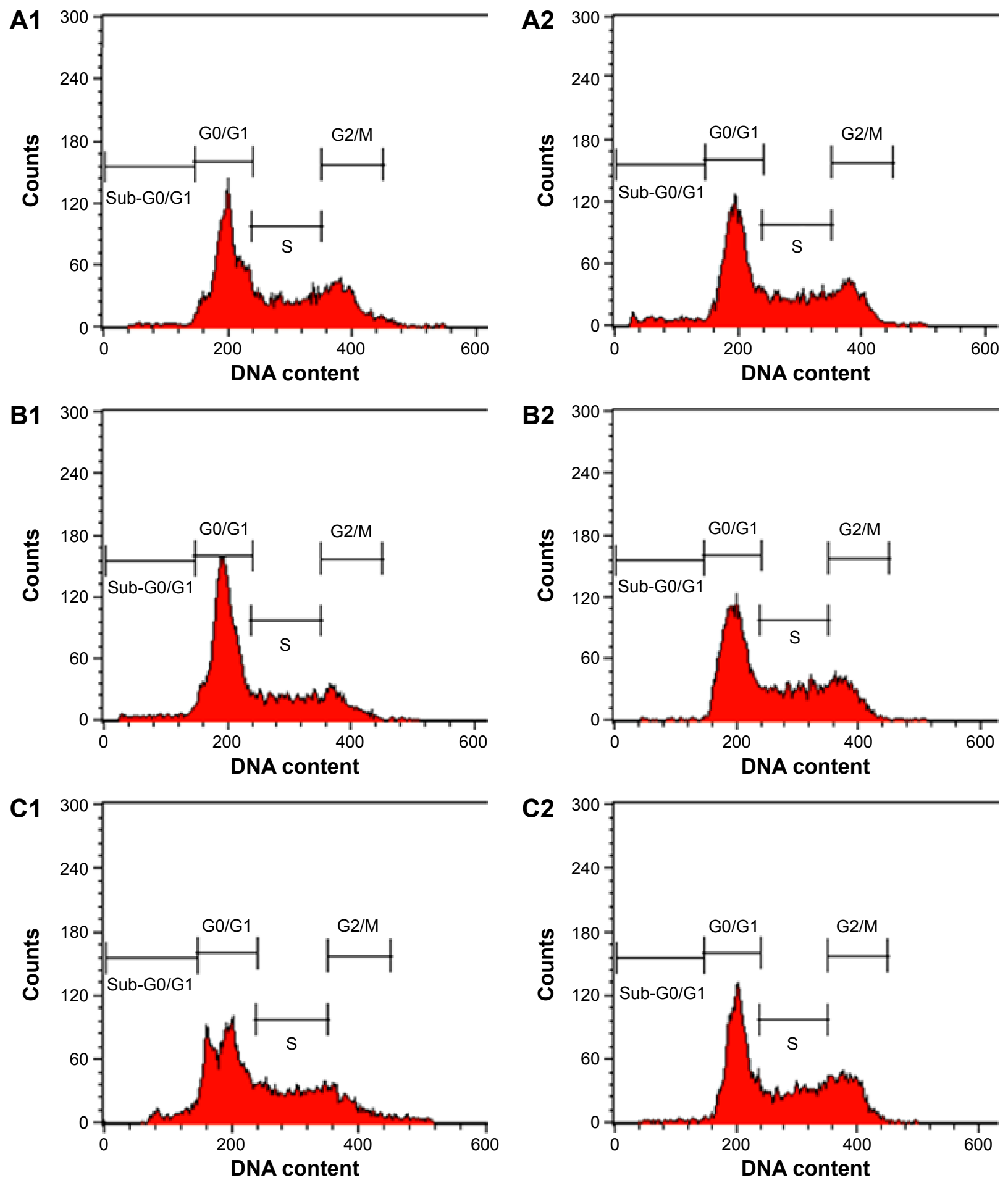

Figure 10 Cell cycle analysis of $\mathrm{HL}-60$ cells treated with $\mathrm{HA} / \mathrm{ZnO}$ nanocomposite after staining with PI.

Notes: (AI-CI) Untreated HL-60 cells for 24 h, 48 h, and 72 h, respectively. (A2-C2) Effects of 24 h, 48 h, and 72 h, respectively, exposure of HL-60 cells to HA/ZnO nanocomposite. G0/GI, G2/M, and S indicate the cell phase, and sub-G0/GI refers to the portion of apoptotic cells.

Abbreviations: $\mathrm{HL}-60$, acute promyelocytic leukemia cells; $\mathrm{HA} / \mathrm{ZnO}$, hyaluronan/zinc oxide; $\mathrm{PI}$, propidium iodide; h, hours. 
Table 2 Flow cytometric analysis of HL-60 cells treated with $\mathrm{HA} / \mathrm{ZnO}$ nanocomposite

\begin{tabular}{lllllll}
\hline $\begin{array}{l}\text { Cell cycle } \\
\text { phases }\end{array}$ & Cells (\%) & \multicolumn{7}{l}{} & \\
\cline { 2 - 7 } & Control 24 h & Treated 24 h & Control 48 h & Treated 48 h & Control 72 h & Treated 72 h \\
\hline G0/GI & $55.25 \pm 0.06$ & $43.40 \pm 0.45$ & $52.10 \pm 0.29$ & $42.61 \pm 0.52$ & $40.64 \pm 0.32$ & $35.68 \pm 0.68$ \\
G2/M & $16.85 \pm 0.76$ & $20.00 \pm 0.41^{*}$ & $19.16 \pm 0.26$ & $26.29 \pm 0.35^{*}$ & $22.30 \pm 0.22$ & $27.06 \pm 0.93^{*}$ \\
Synthesis & $24.91 \pm 0.06$ & $26.30 \pm 0.33$ & $26.24 \pm 0.06$ & $20.93 \pm 0.12$ & $31.50 \pm 0.61$ & $25.35 \pm 0.18$ \\
Sub-G0/GI & $1.9 \pm 0.23$ & $10.50 \pm 0.28^{*}$ & $2.50 \pm 0.34$ & $10.00 \pm 0.20^{*}$ & $6.20 \pm 0.46$ & $13.85 \pm 0.56^{*}$ \\
\hline
\end{tabular}

Notes: The cells were stained with PI and incubated at $37^{\circ} \mathrm{C}$ for $24 \mathrm{~h}, 48 \mathrm{~h}$, and $72 \mathrm{~h}$. Values are expressed as mean \pm SD of three different experiments. Data have been analyzed using post hoc comparison test, one-way ANOVA, and means compared by Tukey's $b$-test. *Significant $(P<0.05)$ increase of cells in sub-G0/GI phase with accumulation and G2/M cell cycle arrest in HA/ZNO nanocomposite-treated groups compared to that of untreated control.

Abbreviations: HL-60, acute promyelocytic leukemia cells; HA/ZnO, hyaluronan/zinc oxide; h, hours; PI, propidium iodide; ANOVA, analysis of variance; SD, standard deviation.

The results show that $\mathrm{HA} / \mathrm{ZnO}$ nanocomposite is potentially an efficacious anticancer agent.

\section{Caspase assay}

The induction of apoptosis by $\mathrm{HA} / \mathrm{ZnO}$ nanocomposite can also be determined by quantitating the activities of caspase-3 and -9 that orchestrate cell death. Caspase- $3,-6$, and -7 coordinate the execution phase of apoptosis by cleaving multiple structural and repair proteins. Activation of caspase-3 is either dependent on or independent of mitochondrial cytochrome $\mathrm{c}$ release and caspase-9 function. In this study, the activity of caspase- 3 and -9 was investigated relative to the protein content of cells after treatment with the $\mathrm{IC}_{50}$ concentrations of $\mathrm{HA} / \mathrm{ZnO}$ nanocomposite. The results showed that the activity of caspases increases in a time-dependent manner (Figure 11; Table 3).

\section{Conclusion}

The fabrication of $\mathrm{HA} / \mathrm{ZnO}$ nanocomposite is a simple, safe, and economical procedure. The zinc oxide nanoparticles with a particle size of $<13 \mathrm{~nm}$ can be incorporated into HA with S. muticum in the reaction medium. This nanocomposite as a drug-delivery vehicle allows for high drug uptake and facilitative drug release into tumor while minimal release into normal tissues. This will enhance the therapeutic efficacy of drugs without causing rampant toxicity to normal tissues. These properties of the $\mathrm{HA} / \mathrm{ZnO}$ nanocomposite can easily be translated into an efficacious therapeutic anticancer drug delivery system with potential for cancer tissue targeting.

\section{Acknowledgments}

The authors are grateful to the staff of Universiti Putra Malaysia, especially those of the UPM-MAKNA-Cancer

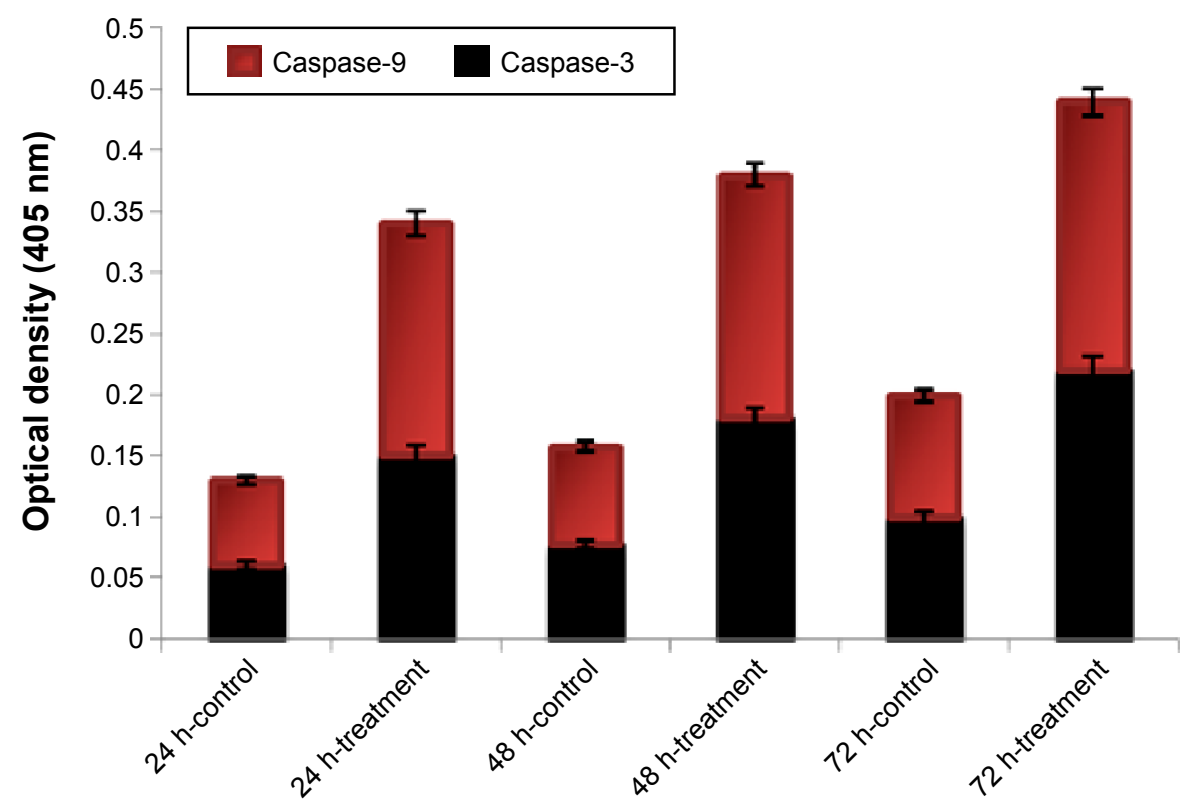

Figure II Effects of $\mathrm{HA} / \mathrm{ZnO}$ nanocomposite treatment on $\mathrm{HL}-60$ cell caspase- 3 and -9.

Notes: The values are mean \pm SD of three independent experiments. Significant differences $(P<0.05)$ between treated and control groups for caspase- 3 and -9 are found. Abbreviations: $\mathrm{HA} / \mathrm{ZnO}$, hyaluronan/zinc oxide; HL-60, acute promyelocytic leukemia cells; h, hours; SD, standard deviation. 
Table 3 Caspases spectrophotometric analysis of HL-60 cells treated with HA/ZnO nanocomposite for $24 \mathrm{~h}, 48 \mathrm{~h}$, and $72 \mathrm{~h}$

\begin{tabular}{lllllll}
\hline Caspase & Cells (\%) & & & & \\
\cline { 2 - 7 } & Control 24 h & Treated 24 h & Control 48 h & Treated 48 h & Control 72 h & Treated 72 h \\
\hline Caspase-3 & $0.060 \pm 0.0012$ & $0.15 \pm 0.00 I^{*}$ & $0.077 \pm 0.005$ & $0.18 \pm 0.0043^{*}$ & $0.099 \pm 0.0032$ & $0.22 \pm 0.006^{*}$ \\
Caspase-9 & $0.069 \pm 0.007$ & $0.19 \pm 0.003^{*}$ & $0.080 \pm 0.001$ & $0.20 \pm 0.0025^{*}$ & $0.12 \pm 0.002$ & $0.24 \pm 0.0035^{*}$ \\
\hline
\end{tabular}

Notes: Values are expressed as mean \pm SD of three different experiments. Data have been analyzed using post hoc comparison test, one-way ANOVA, and means compared using Tukey's b-test. *Significant $(P<0.05)$ increase of apoptotic cells in $\mathrm{HA} / \mathrm{ZnO}$ nanocomposite-treated groups compared to that of untreated control.

Abbreviations: $\mathrm{HL}-60$, acute promyelocytic leukemia cells; $\mathrm{HA} / \mathrm{ZnO}$, hyaluronan/zinc oxide; $h$, hours; ANOVA, analysis of variance; SD, standard deviation.

Research Laboratory, Institute of Bioscience, for their cooperation and technical assistance.

\section{Disclosure}

The authors report no conflicts of interest in this work.

\section{References}

1. Roy M, Nelson JK, MacCrone RK, Schadler LS, Reed CW, Keefe R. Polymer nanocomposite dielectrics-the role of the interface. IEEE Trans Dielectr Electr Insul. 2005;12(4):629-643.

2. Hariraksapitak P, Supaphol P. Preparation and properties of $\alpha$-chitin whisker-reinforced hyaluronan-gelatin nanocomposite scaffolds. $J$ Appl Polym Sci. 2010;117(6):3406-3418.

3. Chong BF, Blank LM, Mclaughlin R, Nielsen LK. Microbial hyaluronic acid production. Appl Microbiol Biotechnol. 2005;66(4):341-351.

4. Pecharki D, Petersen FC, Scheie AA. Role of hyaluronidase in Streptococcus intermedius biofilm. Microbiology. 2008;154(3): 932-938.

5. Armstrong DC, Johns MR. Culture conditions affect the molecular weight properties of hyaluronic acid produced by Streptococcus zooepidemicus. Appl Environ Microbiol. 1997;63:2759-2764.

6. Asteriou T, Deschrevel B, Delpech B, et al. An improved assay for the N-Acetyl-d-glucosamine reducing ends of polysaccharides in the presence of proteins. Anal Biochem. 2001;293(1):53-59.

7. Liu L, Du G, Chen J, Zhu Y, Wang M, Sun J. Microbial production of low molecular weight hyaluronic acid by adding hydrogen peroxide and ascorbate in batch culture of Streptococcus zooepidemicus. Bioresour Technol. 2009;100(1):362-367.

8. Duan XJ, Niu HX, Tan WS, Zhang X. Mechanism analysis of effect of oxygen on molecular weight of hyaluronic acid produced by Streptococcus zooepidemicus. J Microbiol Biotechnol. 2009;19(3):299-306.

9. Lai ZW, Rahim RA, Ariff AB, Mohamad R. Biosynthesis of high molecular weight hyaluronic acid by Streptococcus zooepidemicus using oxygen vector and optimum impeller tip speed. J Biosci Bioeng 2012;114(3):286-291.

10. Rozenberg BA, Tenne R. Polymer-assisted fabrication of nanoparticles and nanocomposites. Prog Polym Sci. 2008;33(1):40-112.

11. Arockiya Aarthi Rajathi F, Parthiban C, Ganesh Kumar V, Anantharaman P. Biosynthesis of antibacterial gold nanoparticles using brown alga, Stoechospermum marginatum (kützing). Spectrochimica Acta A Mol Biomol Spectrosc. 2012;99:166-173.
12. Namvar F, Suhaila M, Fard SG, Behravan J. Polyphenol-rich seaweed (Eucheuma cottonii) extract suppresses breast tumour via hormone modulation and apoptosis induction. Food Chem. 2012;130:376-382.

13. Wada K, Nakamura K, Tamai Y, et al. Seaweed intake and blood pressure levels in healthy pre-school Japanese children. Nutr J. 2011;10(1):83.

14. Rahman HS. Anti-Leukemic Effects of Zerumbone Nanoparticle on Human Jurkat T Lymphoblastoid Cell Lines In Vitro and Murine Leukemic WEHI-3B Model In Vivo. Kuala Lumpur: University Putra Malaysia; 2014.

15. Merisko-Liversidge EM, Liversidge GG. Drug nanoparticles: formulating poorly water-soluble compounds. Toxicol Pathol. 2008;36(1): 43-48.

16. Rahman HS, Rasedee A, Chee WH, et al. Zerumbone loaded nanostructured lipid carriers: preparation, characterization and antileukemia effect. Int J Nanomed. 2013;8:2769-2781.

17. Rahman HS, Abdullah R, Ahmad BA, et al. Zerumbone-loaded nanostructured lipid carrier induces G2/M cell cycle arrest and apoptosis via mitochondrial pathway in human lymphoblastic leukemia cell line. Int J Nanomed. 2014;9:527-538.

18. Hosseinpour M, Abdul AB, Rahman HS, et al. Comparison of apoptotic inducing effect of zerumbone and zerumbone-loaded nanostructured lipid carrier on human mammary adenocarcinoma MDA-MB-231 cell line. J Nanomater. 2014;2014:10.

19. Rahman HS, Rasedee A, Chee WH, et al. Antileukemic effect of zerumbone-loaded nanostructured lipid carrier on murine leukemic (WEHI-3B) model. Int J Nanomed. 2015;10:1649.

20. Donghui F, Beibei W, Zheng X, Qisheng G. Determination of hyaluronan by spectroscopic methods. J Wuhan Univ Technol Mater Sci Ed. 2006;21(3):32-34.

21. Venkatpurwar V, Pokharkar V. Green synthesis of silver nanoparticles using marine polysaccharide: study of in-vitro antibacterial activity. Mater Lett. 2011;65(6):999-1002.

22. Azizi S, Ahmad MB, Namvar F, Mohamad R. Green biosynthesis and characterization of zinc oxide nanoparticles using brown marine macroalga Sargassum muticum aqueous extract. Mater Lett. 2014;116: 275-277.

23. Barros Gomes Camara R, Silva Costa L, Pereira Fidelis G, et al. Heterofucans from the brown seaweed Canistrocarpus cervicornis with anticoagulant and antioxidant activities. Mar Drugs. 2011;9(1):124-138.

24. Azizi S, Ahmad MB, Mahdavi M, Abdolmohammadi S. Preparation, characterization, and antimicrobial activities of $\mathrm{ZnO}$ nanoparticles/ cellulose nanocrystal nanocomposites. BioResource. 2013;8(2): 1841-1851.
OncoTargets and Therapy

\section{Publish your work in this journal}

OncoTargets and Therapy is an international, peer-reviewed, open access journal focusing on the pathological basis of all cancers, potential targets for therapy and treatment protocols employed to improve the management of cancer patients. The journal also focuses on the impact of management programs and new therapeutic agents and protocols on

\section{Dovepress}

patient perspectives such as quality of life, adherence and satisfaction. The manuscript management system is completely online and includes a very quick and fair peer-review system, which is all easy to use. Visit http://www.dovepress.com/testimonials.php to read real quotes from published authors. 